\title{
Любов Осташ
}

Львівський національний університет імені Івана Франка, Львів

\section{Штрихи до наддністрянської оронімії}

\section{1. Ветуп}

Село Стри́га́нці Тисменицького району Івано-Франківської області розташоване в 30-ти кілометрах на північний схід від обласного центру - м. Івано-Франківська. Населення - 972 особи. Площа - близько 14 квадратних кілометрів. Основна його частина міститься на обширній долині правого берега Дністра, на відстані 2-3 кілометрів від самої ріки. Безпосередньо на правому і лівому берегах Дністра знаходиться сусідне село До́вге. Частина Стри́га́нець (кутки Підгора́, Грани́ия, діалектне Грани́ці, частково - Сокови́ия, діалектне Сокови́иі) прилягає до гір або знаходиться на певному підвищенні: Підгора́ - під Сті́нкою, частина Сокови́йі - під Гі́ркою. Грани́ия являє собою пагорок із поступовим підвищенням у напрямку села Ро́шнів, по цьому підвищенні проходить гостинець до села Ро́шнів і далі - через села Юркі́вку, Ми́лування, Вільша́ницю до села Клубі́вці, де Роздоріжжя (діалектне Роздоріжі), а там - центральна дорога до Тисмениці та обласного центру.

Отже, гори є невід’ємною частиною господарської діяльності стриганчан, їм увесь час доводилося і доводиться враховувати особливості рельєфу. Наприклад, на плато гір, назви яких аналізуватимемо нижче, знаходяться найродючіші землі, i тому розрізняють, де в кого яке поле. Тепер, коли розвалився місцевий колгосп, селяни мають по кілька наділів (паїв), один із яких може бути на горі, інший - у долині. Переважна більшість мікротопонімів прямо почерпнута з місцевої діалектної апелятивної лексики.

Земельні ділянки На Доли́ні, як і присадибні ділянки у господарів, що мешкають ближче до Дністра, під час великих повеней (як це було, наприклад, у 1968, 2008 роках) можуть бути підтоплені водою, і врожай може пропасти. Якщо мова йде про земельну ділянку, і не потрібно у розмові уточнювати ії місцерозташування, то в розмові окреслюють загалом: Я се́го ро́ку бу́льбу посади́в На Горі або Я се́го ро́ку На Доли́ні посіяв лише́ бураки́. Однак проблеми з господарюванням На Горі все ж виникають, і пов'яза- 
ні вони передусім із крутизною місцевих доріг (особливо крута дорога на Стінку), оскільки з'їжджати восени з урожаєм не так уже й безпечно. Якщо це навантажений сіном чи іншою сільськогосподарською продукцією віз, то доводиться ланцюгом прив'язувати до основи воза одне 3 коліс, щоб воно не крутилося, а лише ковзало по дорозі.

На сучасних картах переважно вказують висоту лише однісї із стриганецьких гір - 320 м [Карпати. Туристична карта 2009]. Якщо порівняти висоту вказаних навколишніх гір в околицях ближчих і дальших сіл (332 м над рівнем моря в околицях Вільшаниці, 340 в околицях Клубовець, 304 в околицях Маріямполя, 352 в околицях Братишева тощо [Топографічна карта „Івано-Франківська область" 2009]), то стриганецькі гори перебувають у тому ж діапазоні - від 300 до 330 м: ще у 1890 році Stownik geograficzny Królestwa polskiego... подавав висоту стриганецького Сере́дного Го́рба 320 м, а сусідньої $з$ ним гори (очевидно, тієї, де тепер знаходиться грабовий ліс Гай) 327 м [Stownik geograficzny Królestwa polskiego i innych krajów słowiańskich 1890, XI: 427]. Орієнтовно такої ж висоти і Стінкка, яка межує із Сере́дним Го́рбом 3 другого боку, нависає довгою кручею над Стриганцями і тягнеться потім далі в напрямку села До́вгого.

\section{2. Аналіз оронімів околиць села Стриганці}

Кожна із гір, які довгою смугою оточують село і які інколи об'єднують назвою $\mathrm{Ha}$ Горí, має свою окрему власну назву. На їх розгляді ми і зупинимося докладніше.

Бі́лі Берегú. Мара́мпільська Гора́. Поза межами села перед очима жителів Стриганець, якщо вони піднімуться на будь-який свій пагорб, видніється протилежний берег Дністра, який стриганчани називають Білі Береги́. Це високий стрімкий лівий берег Дністра, який простягнувся від села Маріямполя (у 2003-2004 роках за ініціативи сільської ради була відновлена саме ця давня назва) до села До́вгого. Діалектна стриганецька назва цього населеного пункту - Мара́мпіль. Назва Бі́лі Береги́ мотивована білим кольором тих порід, які виходять назовні. Слід сказати, що в околицях Маріямполя (як і Стриганець та навколишніх сіл) багато родовищ вапняків, кременю, алебастру, які у Маріямполі почали активно розробляти у 20 -х роках XIX століття. Лексема бе́ріг активно вживається у мовленні стриганчан і як апелятив (беріг річки), і як ще один мікротопонім: це власна назва місцевості по обидва боки того відрізка річки Корості́льної (правої притоки Дністра), який знаходиться в межах села Стриганці. Пор.: Коли́сь жінки́ ходи́ли пра́ти шма́ті в Бе́ріг.

Висота гір в околицях Маріямполя (304 м над рівнем моря [Топографiчна карта „Івано-Франківська область” 2009]) віддавна використовувалася 
в оборонних цілях. У 1691 р. польський король передав зруйноване містечко Белзецьких Божий Видок-Вовчків краківському каштелянові, великому коронному гетьманові Станіславу Яну Яблоновському (1634-1702) і надав йому привілей на закладення тут фортеці. Замок виріс на місці сторожової вежі міста Вовчкова, неподалік від давнього поселення Чортополь - на високому пагорбі над крутими схилами лівого берега Дністра. Це високі кручі, де майже прямовисні береги ріки 3 двох сторін утворювали неприступний бастіон [Маріямпіль - місто Марії, http://mariampil.if.ua/index/0-10]. Цю гору стриганчани називають Мара́мпільська Гора́ або Гора́ в Мара́мполи.

Правий берег Дністра - низький, пологий. Тому від повеней села Довге і Стриганці захищають кілька валів. По одному з них (насипаний у 20-х роках XX століття) проходить дорога, яка з'єднує село Стриганці із селом Довге. Однак проблемою правобережної частини села Довгого $є$ те, що навіть коли повінь не виллється через дамби і вали, у частині села (з боку Стриганець) на поверхню тоді можуть виступити підгрунтові води, які потім сходять повільно і завдають шкоди жителям.

Гай. Власна назва Гай стосується передусім грабового лісу, який розташований поруч Сере́дного Го́рба. Він росте на схилі і на верху гори, яка відділена від Сере́дного Го́рба глибоким кам'янистим урвищем, хоча там далі, на плато, Сере́дний Горб і ця безіменна гора з'єднуються між собою. Із-за цього, власне, і незрозуміло, чи це окрема гора, чи вона $є$ частиною Сере́дного Го́рба. 3 другого боку цю гору і Гіррку розділяє довгий, зарослий лісом провал, i тільки на південному сході, де провал закінчується, i дорога, яка йде схилом Гі́рки, виходить на верх (за Рога́ткою, де починаються стриганецькі і рошнівські поля і ліси), Сере́дний Горб, безіменна гора і Гі́рка з'єднуються в один масив.

Оця невизначеність статусу гори (окрема гора чи частина Сере́дного Го́рба), помітна й у формулюваннях дослідників кінця XIX століття. Stownik geograficzny Królestwa polskiego... окреслює цю місцевість так: „На сході підноситься Сере́дний горб до 320 м. На південному сході лежить 'Pilipin Haj’ [очевидно, сучасний Гай - примітка наша] з лісовою сторожкою і ліс 'Krakmaw' [назва не збереглася - примітка наша] з пагорбом 327 м”' [Stownik geograficzny Królestwa polskiego i innych krajów stowiańskich 1890, XI: 427]. Отже, назва Гай служить і для назви лісу, і для просторової орієнтації.

Гі́рка. Це гора, яка розташована з правого боку дороги, що тягнеться на схід у поля і ліси. Біля Стриганець ця дорога відділяє Гірку від Сере́дного Го́рба і Га́ю. На високому пагорбі (своєрідному підніжжі гори) розташована старовинна дерев'яна церква (зараз завершується будівництво нової церкви), також сільський цвинтар. Вище знаходиться вершина гори, яка довгим і широким пасмом тягнеться в напрямку до села Рошнева.

Назва Гірка, зменшувальне від гора 'підвищення', у східнослов'янському ономастиконі досить поширена. Це і народна географічна лексика, 
і мікротопоніми, і ойконіми. Наприклад, на території Кіровоградської області гі́рка - це: 1. Гора, горб, підвищення. 2. Схил невеликої гори, горба, підвищення [Громко, Лучик, Поляруш 1999: 56]. На Волині знаходимо ойконіми Гірка Полонка, Гірки. Як зазначає В.П. Шульгач, за матеріалами М. Фасмера, у межах Східної Славії було відомо 341 аналогічне найменування [Шульгач 2001: 32]. На території Івано-Франківщини відомі ще 5 оронімів Гірка [Габорак 2005: 70].

Зараз вершина Гірки та іï схили з боку Стриганець голі, не зарослі лісом. Вони використовуються як пасовисько. Хоча ще у передвоєнні роки на ній виростав ліс, який мав промислове значення. За спогадами старожилів, приїжджали навіть голландські купці, щоб купити сосни для будівництва кораблів, однак ліс виявився ще замолодим. Ліси (переважно соснина) на стриганецькій Гіриі вирубали під час Другої світової війни і після неї місцеві жителі і мешканці з навколишніх сіл для будівництва своїх осель.

3біч. Збіч являє собою високий схил, який розташований на території самого села і тягнеться півколом із заходу на схід майже від початку гори, на якій міститься стриганецький ліс Шкве́риш до дороги (гостинця), що з'єднує Стриганці з Рошневом. Схил місцями дуже крутий і порослий лісом. Унизу, під ним - присадибні ділянки стриганчан. На своєму верху він починає своєрідну терасу, яка поступово підвищується на південь у напрямку рошнівських горбів. На цій терасі також розташовані садиби і присадибні ділянки стриганчан (охоплюють частину кутка Село́ і куток Грани́ия). Власна назва утворилася від діалектного апелятива збіч 'схил'. Ця лексема у народній географічній лексиці у тому чи іншому фонетичному або словотвірному оформленні фіксується і в інших регіонах України, пор., наприклад збо́чя 'схил гори' у Кіровоградській області [Громко, Лучик, Поляруш 1999: 83].

\section{Мара́мпільська Гора́ див. Бі́лі Берегú.}

Сере́дний Горб. Назва цієї гори відома віддавна. Вона згадується ще 3 кінця XIX століття [Stownik geograficzny Królestwa polskiego i innych krajów stowiańskich 1890, XI: 427]. Протягом другої половини XX століття верх Сере́дного Го́рба, який нависає над селом, - це переважно пасовисько, хоча далі, вглиб по плато, його намагалися розорювати під сільськогосподарські культури. Зараз по краю він заростає лісом. У кінці 60-х - протягом 70-х років XX століття під Сере́дним Го́рбом функціонувала цегельня (діалектне uзиго́льні), яку організував стриганецький колгосп. Внаслідок цього нижня частина Сере́дного Го́рба частково пошкоджена.

Назва Сере́дний Горб утворена шляхом лексикалізації та онімізації словосполучення, у якому опорним компонентом $€$ апелятив го́рб, а атрибутивним означенням - прикметник сере́дний (діалектне сере́дний 'середній'), що вказує на місцезнаходження гори стосовно інших орооб'єктів [Габорак 2005: 267]. 
Скала́. Скала́ - це частина гори Стінка. Вона розташована поблизу вулиці Мала́ Цари́нка і являє собою прямовисну кам’яну стіну під верхом пагорбу. Нижче, при спуску в долину вона також крута, але не така прямовисна, як вверху. Скала́ давала стриганчанам пряму вигоду: це була каменоломня. Десь до початку 70-х років XX століття у Скалі видобували камінь для спорудження будинків у селі. Господар, який планував будувати хату чи стайню, із чоловіками-родичами (або найманими за гроші робітниками-односельчанами) йшов у Скалу́ лупа́ти ка́мінь. Видовбані $з$ допомогою молотів, залізних ломів та іншого знаряддя каменюки різних розмірів скидали з-під верху гори, вони скочувалися по схилі і зупинялися аж унизу. Потім при потребі їх роздрібнювали і надавали потрібної для будівництва форми. Із розвитком виробництва цегли у навколишніх населених пунктах (зрештою, у минулому кілька років і під Сере́дним Го́рбом функціонувала цегельня місцевого колгоспу) лупати камінь перестали, усі будинки у селі вже будують із цегли. Навколо Скали́ зараз уже все заросло лісом, тільки де-не-де видніється біле каміння. Назва утворена семантичним способом від діалектного апелятива скала́ 'скеля; крутий прямовисний берег'. На території Івано-Франківської області існує ще кілька орооб'єктів із назвами, що містять у своєму складі лексему скала́ [Габорак 2005: 272-274].

Сті́нка. Стінка є горою, яка досить довгим масивом тягнеться аж до Дністра. Край цієї гори з боку Стриганець у багатьох місцях прямовисний. За переказами, Дністер у давнину протікав саме попід Стінку, а вже потім поступово його русло пересувалося долиною у протилежний бік (де зараз Бїлі Берегú). У 60-х роках XX століття стрімкий схил Стінки на території Стриганець був переважно голим, не зарослим лісом. На вершині гори починається і тягнеться далі, углиб від села, плоска поверхня з родючими грунтами. Колгосп розорював ці землі під сільськогосподарські культури (переважно там росла кукурудза) майже до самого краю, до урвища. Залишалася невелика смуга, де селяни й випасали свою (не колгоспну) худобу, оскільки в ті часи 3 пасовиськами для індивідуального випасу худоби, із-за утисків колгоспного керівництва, було дуже скрутно. Тепер ситуація змінилася: на території цих грунтів розташовані земельні наділи стриганчан, а стрімкий схил і значна частина території поблизу схилу заросли густим, високим лісом.

Власна назва утворена семантичним шляхом від апелятива стінка 'крутий схил гори; крутий прямовисний берег; стрімка гора, круча, обрив’. На території Івано-Франківщини наявні ще 7 оронімів із такою назвою [Габорак 2005: 287-288].

Шкве́риш. Шкве́риш, як і Гай, це передусім назва лісу. Його особливістю $€$ те, що він розташований на південному заході села на горі, яка $є$ частиною довгого пасма, що тягнеться на захід попри село Побережжя до села Ганусівка. Окремої назви у стриганчан ця гора не має, можливо, тому, що на її плато знаходяться поля уже інших сіл, зокрема, Рошнева, а стриган- 
чани користають лише 3 лісу. Ліс інтенсивніше використовувався раніше, коли потрібні були дрова на зиму або будівельний матеріал. Тепер у селі проведено стаціонарний газ, а будівельний матеріал можна вільно закупити у відповідних фірм та організацій. Отже, власна назва лісу Шкве́риш одночасно окреслює для мешканців Стриганець і місцезнаходження гори, на якій він розташований, але не $\epsilon$ оронімом. У цьому сенсі його функція така ж, як власної назви лісу Гай - називати ліс та окреслювати місцезнаходження гори у мовленні місцевих мешканців, однак сам орооб'єкт не називати.

На даному етапі дослідження встановити походження та етимологію топоніма Шкве́риш нам не вдалося.

\section{3. Висновки}

Отже, місцеві орооб'єкти активно включені у господарську діяльність людей. Особливість географічного розташування села і сільськогосподарських угідь полягає в тому, що частина їх розташована в долині Дністра, а частина - на вершинах навколишніх гір, які на певній відстані від села утворюють єдине плато, що тягнеться на схід від села у напрямку Дністра. Тому у розмовному мовленні вживають і узагальнюючі назви ( $\mathrm{Ha} \mathrm{\Gamma opi,} \mathrm{Ha}$ Доли́ні), і конкретні стосовно кожної окремої гори (на Стіниі, на Сере́дному Го́рбі, на Гіриі, над Збоче́м). Сучасна оронімія села Стриганці і його околиць (у мовленні стриганчан) базується на народній географічній лексиці. Гори, які оточують село і біля підніжжя яких воно частково також розташоване, мають власні назви, утворені лексико-семантичним способом від апелятивів, які функціонують або в українській літературній мові, або в діалектному мовленні: Гі́рка, Збіч, Сере́дний Горб, Стінка, Скала́. Власних назв іншомовного походження в оронімії Стриганець немає.

\section{Бібліографія}

Габорак Мирослав, 2005, Назви гір Івано-Франківщини, Івано-Франківськ.

Громко Тетяна, Лучик Василь, Поляруш Тамара, 1999, Словник народних географічних термінів Кіровоградщини, Київ, Кіровоград.

Карпати. Туристична карта, 2009, Київ.

Маріямпіль - місто Марії, http://mariampil.if.ua/index/0-10

Топографічна карта „Івано-Франківська область”, 2009, Київ.

Шульгач Віктор, 2001, Ойконімія Волині, Київ.

Stownik geograficzny Królestwa Polskiego i innych krajów słowiańskich, 1890, t. XI, Warszawa. 


\title{
Lyubov Ostash
}

\section{Features of upper Dniester oronymy}

\author{
(Summary)
}

The village of Stryhantsi of Tysmenytsya District, Ivano-Frankivsk Region is located $30 \mathrm{~km}$ northeast of regional centre - city of Ivano-Frankivsk. It is considered to be founded in 1624. The village was mentioned on the map of the French engineer-cartographer Le Vasseur de Beauplan since 1650 . Its basic part is located in a wide valley of the right bank of Dniester, $2-3 \mathrm{~km}$ of the very river. Local oro-objects are actively included into economic activity of people. Peculiarity of geographical location of the village and agricultural areas lies in the fact that part of them is located in the valley of Dniester, and the other part is located on tops of surrounding mountains which form a single plateau within a certain distance of the village that stretches to the east of the village towards Dniester. Therefore, both generalizing names ( $\mathrm{Na} \mathrm{Hori,} \mathrm{Na} \mathrm{Dolyni)} \mathrm{and} \mathrm{specific} \mathrm{names} \mathrm{as}$ to each separate mountain (na Stintsi, na Serednyomu Horbi, na Hirtsi, nad Zbochem) are used in colloquial speech. Modern oronymy of the village of Stryhantsi and its surroundings (in the language of Stryhantsi residents) is based on folk geographical lexis. Mountains surrounding the village and at the foot of which it is partially located have proper names formed in lexico-semantic way from appellatives which function either in Ukrainian literary language or in dialect speech: Hirka, Zbich, Seredniy Horb, Stinka, Skala. There are no proper names of foreign origin in oronymy of the village of Stryhantsi. Modern oronymy of the village of Stryhantsi and its surroundings is based on folk geographical lexicon. Mountains surrounding the village have their proper names created in lexico-semantic way from appellatives that function either in Ukrainian literary language or in Ukrainian dialect speech: Hirka, Zbich, Seredniy Horb, Skala, Stinka.

Slowa kluczowe: nazwa własna, oronim, mikrotoponim, gwary naddniestrzańskie.

Key words: proper name, oronym, microtoponym, Upper Dniester dialect. 